\title{
LITERATUUR
}

\section{Overzicht Literatuur januari t/m mei $2017^{*}$}

\author{
Boeken
}

Stephen Egharevba, Police Brutality, Racial Profiling, and Discrimination in the Criminal Justice System, IGI Global 2017, ISBN: 9781522510888

Inhoud:

In order to protect and defend citizens, the foundational concepts of fairness and equality must be adhered to within any criminal justice system. When this is not the case, accountability of authorities should be pursued to maintain the integrity and pursuit of justice.

Police Brutality, Racial Profiling, and Discrimination in the Criminal Justice System is an authoritative reference source for the latest scholarly material on social problems involving victimization of minorities and police accountability. Presenting relevant perspectives on a global and cross-cultural scale, this book is ideally designed for researchers, professionals, upper-level students, and practitioners involved in the fields of criminal justice and corrections.

Pauline Kruiniger (red.), Recht van de Islam en het Midden-Oosten (deel 30), Boom juridisch 2017, ISBN 9789462903111

Inhoud:

Dit zijn de teksten van het op 2 juli 2015 te Leiden gehouden 33ste RIMO-symposium: 'Jihad, islam en recht. Jihadisme en reacties vanuit het Nederlandse en Belgische recht'.

Michael J. Flynn and Matthew B. Flynn (ed.), Challenging Immigration Detention. Academics, Activists and Policy-makers, To be published September 2017, Edward Elgar, ISBN: 9781785368059

Inhoud:

Immigration detention is an important global phenomenon increasingly practiced by states across the world in which human rights violations are commonplace. Challenging Immigration Detention introduces readers to various disciplines that have addressed immigration detention in recent years and how these experts have sought to challenge underlying causes and justifications for detention regimes. Contributors provide an overview of the key issues addressed in their disciplines, discuss key points of contention, and seek out linkages and interactions with experts from other fields.

* Deze rubriek is samengesteld door de redactie van Crimmigratie \& Recht. 
C.E.D. Maas, M. Huibers en M.J.J. Kunst, De Pilot Verhoorstudio's in opvanglocaties voor slachtoffers van mensenhandel, Boom criminologie 2017, ISBN 978 9462367463

Inhoud:

Mensenhandel wordt beschouwd als een van de ergste vormen van criminaliteit en gaat samen met grove schendingen van mensenrechten. Slachtoffers kunnen een belangrijke rol spelen in de opsporing van dit misdrijf. Zij kunnen de politie namelijk informatie verstrekken over het misdrijf en de dader(s). Dat zullen zij echter alleen doen indien zij vertrouwen in de politie hebben en zich voldoende veilig voelen. Om hun gevoel van vertrouwen in de politie en hun gevoel van veiligheid te bevorderen, heeft de politie in 2014 verhoorstudio's ingericht binnen een aantal opvanglocaties voor slachtoffers van mensenhandel. Hierdoor kunnen slachtoffers in een vertrouwde en veilige omgeving gehoord worden door de politie. In dit boek wordt onderzocht wat de gevolgen van deze beleidsmaatregel zijn geweest. Het gaat hierbij om een eerste verkenning van de resultaten.

Dit boek is in de eerste plaats bedoeld voor beleidsmedewerkers van de politie, het Openbaar Ministerie en het Ministerie van Veiligheid en Justitie. Daarnaast is het boek waardevol voor politieambtenaren die regelmatig in aanraking komen met slachtoffers van mensenhandel, voor studenten, onderzoekers en anderen die geïnteresseerd zijn in het thema mensenhandel.

\section{Boekbijdragen}

Mary Bosworth, 'Border criminology and the changing nature of penal power', in: Alison Liebling, Shadd Maruna \& Lesley McAra (ed.), The Oxford Handbook of Criminology, Oxford University Press 2017, ISBN: 9780198719441.

\section{Artikelen}

Special issue European Journal of Criminology (diverse artikelen), Crimmigration in Europe, 2017-1 (vol. 14).

Special issue New Criminal Law Review (diverse artikelen), Criminal Justice Adjudication in an Age of Migration, 2017-1 (vol. 20).

Maria Sobolewska, Silvia Galandini \& Laurence Lessard-Phillips, 'The public view of immigrant integration: multidimensional and consensual. Evidence from survey experiments in the UK and the Netherlands', Journal of ethnic and migration studies 2017-1 (vol. 43).

Jim Waasdorp, 'Kroniek vrijheidsontneming', Asiel \& Migrantenrecht 2017-1.

Emily Ryo, 'Legal attitudes of immigrant detainees', Law \& Society Review 2017-1 (vol. 51), p. 99-131. 
Karina Moreno \& Byron Eugene Price, 'The social and political impact of the new (private) National Security: private actors in the securitization of immigration in the U.S. post 9/11', Crime, Law and Social Change 2017-3 (vol. 67), p. 353-376.

Saba Ahmed, Adina Appelbaum \& Rachel Jordan, 'The Human Cost of IIRIRA Stories From Individuals Impacted by the Immigration Detention System', Journal on Migration and Human Security 2017-1 (vol. 5), p. 194-216.

Nancy Hiemstra \& Deirdre Conlon, 'Beyond privatization: bureaucratization and the spatialities of immigration detention expansion', Territory, Politics, Governance 2017-1, p. 1-17.

Andrea Gómez Cervantes, Cecilia Menjívar and William G. Staples, "Humane” Immigration Enforcement and Latina Immigrants in the Detention Complex', in: Feminist Criminology 2017-1.

Jim Waasdorp \& Aniel Pahladsingh, 'Expulsion or Imprisonment? Criminal Law Sanctions for Breaching an Entry Ban in the Light of Crimmigration Law', Bergen Journal of Criminal Law \& Criminal Justice 2017-2 (vol. 4).

Amada Armenta, 'Racializing Crimmigration', Sociology of Race and Ethnicity 2017-1 (vol. 3), p. 82-95.

J. Brouwer, J. van der Leun \& M. van der Woude, '( $\mathrm{Cr}$ )immigrant framing in border areas: decision-making processes of Dutch border police officers', Policing and Society 2017-1, p. 1-16.

Amada Armenta \& Isabela Alvarez, 'Policing immigrants or policing immigration? Understanding local law enforcement participation in immigration control', Sociology Compass 2017-2 (vol. 11).

Alessandro Spena, 'A Just Criminalization of Irregular Immigration: Is It Possible?', Criminal Law and Philosophy 2017-2 (vol. 11), p. 351-373.

A. Aliverti, 'The wrongs of unlawful immigration', Criminal Law and Philosophy 2017-2 (vol. 11), p. 375-391.

E.M.J. Lentze, 'Het EVRM en een strafbaarstelling voor overtreding van een visumsysteem in de strijd tegen het terrorisme', Proces 2017-1.

U. d'Oliveira, 'Geen directe werking Europees Nationaliteitsverdrag? So what!', Nederlands Juristenblad 2017-2, p. 118-121.

S. Meijer, 'De invloed van de strafrechter op de bijkomende gevolgen van de straf. Pleidooi voor een meer integrale benadering tussen de straftoemetingsbeslissing en de bestuursrechtelijke beslissing', Delikt en Delinkwent 2017-16. 